\title{
Why we think it is important to discuss intelligent design
}

\begin{abstract}
Belief in God and belief in the science of evolution are not mutually exclusive concepts. Thousands of scientists who believe in God are able to separately study and teach evolution. As scientists and parents, we owe it to our children to ensure that public school science curricula teach the science of evolution and not promote a particular religious faith or belief system.
\end{abstract}

Both of us follow distinct organized religions (Jainism and Judaism) and believe in God. Yet we both also understand that humans evolved from primate ancestors, as do all of our colleagues with whom we have discussed this issue. It is worth noting that while the scientific understandings of evolution have advanced dramatically in the past 100 years, so has involvement in organized religion in the United States - de facto proof that these two seemingly competing systems of thought are actually compatible.

It has been a tenet in this country that the public school system should not engage in the teaching of religion. This is especially so in science class. Parents who want their children to learn about the Bible, including the story of creation, are free to send them to religious school either in addition to their regular curriculum or in its stead. This is a free country, in which such choices abound.

Yes, the JCI is a biomedical research journal that primarily publishes articles pertaining to human diseases. So why all the interest in intelligent design (ID)? As we stated before (1), this is not the time to have our heads in the sand and leave the fight to others. As an example of how you can get involved, in this issue we publish an article from authors in Wisconsin who have helped stop the teaching of ID in their state (2).

The response we received to our previous editorial on this subject (1) was very polarized. While the debate about ID goes on, we believe that the pages of the JCI are an appropriate forum in which to express support for the separation of science and religion. At a time when the separation of church and state is being challenged by the Bush administration's policies, including the regressive ban on stem cell research, the equally important right to teach and learn biology must be defended by all scientists.

\section{Ushma S. Neill \\ Executive Editor}

\section{Andrew R. Marks \\ Editor in Chief}

1. Neill, U.S. 2005. Don't be stupid about intelligent design [editorial]. J. Clin. Invest. 115:2586. doi:10.1172/JCI26727.

2. Attie, A.D., et al. 2006. Defending science education against intelligent design: a call to action. J. Clin. Invest. 116:1134-1138. doi:10.1172/ JCI28449. 